\title{
Rural and Urban EFL Teachers and Students' Attitude toward Using L1 in Iranian English Classrooms
}

\author{
Mina Reaisi* \\ Department of English, Isfahan (Khorasgan) Branch, Islamic Azad University, Isfahan, Iran \\ Hossein Ghaiyoomian \\ Department of English, Sheikhbahaee University, Isfahan, Iran \\ Massome Raeisi \\ Department of English, Shahreza Branch, Islamic Azad University, Shahreza Branch, Iran
}

\begin{abstract}
This study aimed to explore students' attitude toward the effect of using translation from L1 to L2 on improving English accuracy. It carried out in a junior high school in Isfahan, Iran and administered in two phases, one with teachers and another with students. The qualitative approach and survey design were exploited to conduct the research. The participants of the study were 30 students and they were given two sets of questionnaire. Findings showed that EFL teachers and students in rural areas used L1 no more than teachers and students in urban EFL classrooms. Results have shown that there is not any significant relationship between the use of translation and the students' attitudes towards the use of L1. They also indicated that there is a significant relationship between the method of teaching and the students' attitudes towards using L1 in EFL classroom. The findings of this study can be useful for EFL students as well as teachers to enhance the efficiency and productivity of bilingual classes.
\end{abstract}

Index Terms —attitude, L1, rural, student, teacher, urban

\section{INTRODUCTION}

Discussions regarding the use of L1 and FL are common among Iranian EFL students. As Israt Jahan Shuchi \& A B M Shafiqul Islam (2016) maintained, the controversial issue among learners who are not satisfied with their undefined role in EFL and ESL classes has a long background in history. Students believe that since they do not understand the lesson entirely in English, they might experience fear, insecurity, and low self-esteem. As a result, these students do not feel at home in EFL classrooms and may not be able to participate well in the learning process. Nevertheless, other students complain about L1 use in FL classrooms and talk about the limitations of using L1 while practicing FL.

The research purpose was to explore junior high school teachers' and students' attitudes towards the use of Persian in Iranian rural and urban EFL classrooms.

This research is conducted in two related parts.

The study investigated rural and urban junior high school teachers' and students' attitudes towards the use of Persian in Iranian EFL classrooms which is a missing part in previous research in the first section.

The second section of this study examines the effect of using translation as a teaching technique on the students' attitudes towards the use of L1.

The research objectives followed these research questions

1. What are Iranian rural and urban EFL teachers' and students' attitudes toward the use of L1 in English classrooms?

2. What is the effect of using translation on students' attitudes towards L1 use?

The role of L1 as a learning strategy used by EFL learners directly or indirectly is undeniable as Ellis (2008) states that L1 evidently affects L2 acquisition. It is vitally important to learn grammar of the target language in the elementary levels of FL learning. The reason is that basic and fundamental grammars should be learned at this level; additionally teaching these structures in a more comprehensible and retrievable manner would provide a condition for getting advanced grammatical structures. Providing a balance between the use of L1 and L2 is of crucial importance. Therefore, exploring Iranian rural and urban EFL a teachers' and students' attitude toward the use of L1 in English classrooms is a significant issue.

Studying the attitudes of EFL teachers and students towards the use of L1 has been the subject of many research studies which some of them will be discussed in the section of literature review. Nevertheless, studying attitudes at

* Corresponding Author 
lower levels like Iranian junior high schools has been disregarded. Students at this level face various emotional, physical, educational, and cultural problems that underestimating them would create greater problems. So paying attention to these students' attitudes towards language learning and researching for better methods and materials is worth investigating.

One part of this study focused on students' and teachers' attitudes towards the use of L1 by considering place of education, rural or urban, as an independent variable. In Iran, schools in urban and rural areas are somehow different when it comes to FL learning and teaching issues. Considering some of these differences can shed light on the rationale behind choosing this issue as the subject of the present study.

The most important difference between FL learners in rural and urban areas is the accessibility to language institutes. Most students in rural districts do not have access to language institutes and FL classes at schools are the first and perhaps the only language classes they can experience while many of urban students' experience at least a couple of terms of language learning out of school curriculum. These urban students feel more at home in FL classrooms at schools and have less affective problems.

Teachers in rural schools are sometimes non-qualified. At low levels like junior high school some teachers who have not any degrees in English accept to teach as an English teacher. Although this is a problem even in some schools in cities, it is more common in rural areas because the number of classes is limited and a teacher has to teach various subjects to fill up his/her weekly teaching schedule.

Students' views towards education and especially FL learning in rural schools are a little bit different from those of urban students. Due to lack of FL learning experience some rural students underestimate their talents and abilities and view language learning something beyond their grasp. They underestimate their expectations of FL learning because they think that even without FL skills they can follow their parents' career. In rural areas, students learn the educational materials relying on their own capabilities and not necessarily the explanations their teachers provide them with. In other words, they depend on their own abilities while in the urban districts students do not rely on their teachers and are not as teacher-oriented as the students in rural areas.

\section{THEORETICAL BACKGROUND}

Skuttnab-kangas (2000) commented:

"Despite the small recent improvements, it seems clear that countries have so far not respected what should be basic linguistic human rights, especially in education, and that the world so far does little to prevent linguistic and cultural genocide" (p. 563).

Skuttnab-kangas pointed out that there are two forms of mother tongue maintenance. In the weaker form, pupils are given classes in their mother tongue and in the stronger form, pupils are educated through the medium of their mother tongue.

Anton and DiCamilla $(1999,234)$ present a socio-cultural theory. They very clearly explain that Vygotsky's zone of proximal development (ZPD) provides "an opportunity, through L1, for learning with and from others" whereby one's ZPD expands through collaboration. They highlight comprehension checks, clarification requests, confirmation checks, and repetition, etc. as examples of learner interaction. Again, in their own impressive research, they conclude that L1 is beneficial to learning in that it acts as a "critical psychological tool ... by performing three key functions: construction of scaffold help, establishment of intersubjectivity and the use of private speech" (ibid., 245).

Gabrielatos $(2001,2)$ responds to the metaphoric claim by Prodromou $(2001)$ that the L1 has been a skeleton in the closet of ELT for a long time because there has not been a psycholinguistic or pedagogic framework within which to discuss the use of the MT. Gabrielatos demonstrates, in fact, there are a number of frameworks available. There are semantic, pragmatic, psycholinguistic and inter-language theory frameworks that all offer an opportunity for exploring the use of L1 in the classroom. He claims that they were neglected because they did not fit into existing frameworks. He concludes that "an either/or [EO or BI] attitude to L1 use in ELT is not helpful" and instead suggests a series of questions about using the MT such as "what for", "when" and "to what extent" (Gabrielatos, 2001, 4).

Background of the study

In order to find out the benefits and positive sides of using L1 in the FL learning, Rolin- Ianziti and Brownlie (2002) in their research investigated the role of L1 with four teachers at an Australian university. Results of this research have shown that L1 can be used mostly for establishing a non-threatening classroom environment, explaining grammar, translating vocabulary, managing classroom, and giving instruction (p. 417). They conclude that L1 use for translation modifies input for the FL learners.

Translation can also be used as a productive means to learn new L2 vocabulary. Based on the most recent understanding of vocabulary storage, bilinguals access one common storage system containing both L1 and L2 vocabulary. Therefore, L1 is considered to assist learners' comprehension of L2 resulted by creating more networks between nodes (ideational representation and words) in their long term memory. As a result, translation have can absorb teacher's attention and let them focus on the words and structures that demand more exercise (Van Els et al., 1984).

Dujmovic (2007) examined the attitudes of his 100 EFL students. He concluded that his students responded positively to the use of L1 in L2 context and showed their interests as well. 
Karathanos (2005; cited in Samadi, 2011) carried out another research about L1 that teachers use in L2 classrooms. In her research, self-reported attitudes of 327 L2 teachers in the state of Kansas, USA were examined. According to the results, teachers accepted and used the idea of using L1 in L2 teaching; therefore, a positive relationship between ESLspecific university education and an increased support for L1 use was found. Another interesting result of this research was that in comparison with the female teachers, the male ones ESL-specific university education supported the idea of using L1 in the ESL classrooms (p. 88).

A majority of students, from $66 \%$ to $89 \%$, believe that the MT should be used in the classroom (Burden 2000; Prodromou 2002; Schweers 1999). On the other hand, Storch and Wigglesworth $(2003,766)$ report that intermediate level students in university were reluctant to use their shared MT because it would slow down their progress in an activity by adding another unnecessary step (translation from L1 to L2) and, furthermore, they intrinsically believed they should use as much TL as possible in class.

Raeisi and Raeisi (2019) conducted a research and analyzed code-switching cases and explored their inter-sentential and intra-sentential patterns in Persian-English bilingual classroom. According to the results, the pattern of codeswitching can be categorized into five categories and three subcategories of shifting to give explanation in cultural issues, shifting to avoid misunderstanding, and shifting for elaborating grammatical matter. The interesting point of their study was that intra-sentential patterns were used less than inter-sentential code-switching patterns.

To sum up, it might be appropriate to quote the following words of Deller and Rinvolucri (2002): "The mother tongue taboo has been with us for a long time, but fortunately now things seem to be changing" therefore, the reason why most of the teachers tend to use it is because of its effectiveness and necessity of mother tongue. (p. 3).

\section{MethodOLOGY}

This research is of qualitative approach based on survey design.

Participant: The participants of the study were 30 students. 15 students from the experimental group and 15 students from the control group were randomly given the students' questionnaire to check the probable effect of mode of teaching on the students' attitudes towards the use of L1.

Instruments: In the second phase of the study two questionnaires, one intended for learners with 15 items and one for teachers containing 14 items were devised to measure EFL students and teachers' beliefs about the use of L1 in EFL classrooms.

It is worth noting that the original versions of these questionnaires were extracted from Samadi's (2011) research thesis and a lot of simplification and modification was done to them to be applicable for this research study because he studied the attitudes of university students and teachers who were at higher levels of language proficiency than the participants of the present study. For example, for simplification purposes the number of items in the questionnaires was decreased from 27 to 15 for students and from 19 to 14 for teachers. Some items such as the following were originally part of the questionnaires.

1. When teachers use L1 in English classrooms, students speak more L1 than English in the classroom.

2. I often feel like not going to my English class because I do not understand what the teacher says in English.

3. I get nervous when I take a test in English in which all directions are in English.

Because some of the items were not as effective as the other factors to satisfy the purpose of the research, the foregoing items were extracted. Furthermore, some of the items were repeated with different wording. The wording of the questionnaires was also refined to be comprehensible for low level students. The new versions of the questionnaires were given to three junior high school teachers to be corrected and refined. Based on these teachers' comments, the questionnaires were changed and revised. For instance, teachers commented that it is better to change the format of 5 point Likert-type rating scale to 1 indicating 'strong disagreement', 2 'disagreement', 3 'no opinion', 4 'agreement', and 5 'strong agreement' with each item on the questionnaires. The original rating scale allocated these numbers in the opposite direction (5 instead of 1 for instance) which is not considered the most acceptable style in Likert-type rating scale.

The final versions of the questionnaires were given to eight students and teachers as a pilot test for identifying the reliability of the questionnaires. Analyzing the results through SPSS revealed the Cronbach's Alpha to be 0.736 and 0.719 for teachers and students' questionnaires respectively. And since the Cronbach's Alpha above 0.7 is considered acceptable the questionnaires were revealed to be reliable and of acceptable levels of internal consistency. The following Tables show the reliability statistics of the questionnaires obtained using SPSS.

TABLE 1

CRONBACH'S ALPHA FOR STUDENTS' QUESTIONNAIRE

\begin{tabular}{lll}
\hline N of items & $\begin{array}{l}\text { Cronbach's Alpha } \\
\text { based on } \\
\text { standardized items }\end{array}$ & $\begin{array}{l}\text { Cronbach's } \\
\text { Alpha }\end{array}$ \\
\hline 14 & .744 & .736 \\
\hline
\end{tabular}

As it is considerable in Table 1, all of the items were 14 that its Cronbach's Alpha based on standardized items was 0.744 and its own Cronbach's Alpha was 0.736. 
TABLE 2.

\begin{tabular}{lll}
\multicolumn{2}{c}{ CRONBACH'S ALPHA FOR TEACHERS' QUESTIONNAIRE } \\
\hline N of items & $\begin{array}{l}\text { Cronbach's alpha } \\
\text { based on } \\
\text { standardized items }\end{array}$ & $\begin{array}{l}\text { Cronbach's } \\
\text { Alpha }\end{array}$ \\
\hline 15 & .802 & .719 \\
\hline
\end{tabular}

Based on Table 2, the whole number of the items were 15 that its Cronbach's Alpha based on standardized items was 0.802 and its own Cronbach's Alpha was 0.719.

\section{DATA ANALYSis AND Result}

To carry out the main objective of the present study, the obtained data were subjected to a number of statistical analyses by using statistical package for social sciences (SPSS 17.0.).For analyzing the data obtained from the questionnaires the items on each questionnaire were divided into seven groups. The first group was allocated to the items relating to the amount of L1 use by teachers and students which covered 4 items in each questionnaire.

Analyzing the data for the last part of the study was similar to the second part. The group of items reflecting on the amount of L1 use in EFL classrooms was the focal point in this phase of the study. Again the data was classified and entered into SPSS to test the last hypothesis of the study for determining the probable effect of teaching method on the students' attitudes towards L1 use.

Teachers and Students' Attitudes towards Using L1

A questionnaire of 19 items for teachers and a questionnaire of 27 items for students were the original forms shortened and modified to be applicable for this research purposes. It is worth mentioning that the questionnaires were originally extracted from Samadi's (2011) MA thesis which its topic was measuring the ideas and opinions of the EFL learners' and teachers to find a connection between the gender of both teacher and learner and L1 usage. The modified questionnaires were given to three junior high school teachers and their suggestions were adopted to have a 14-item questionnaire for teachers and a 15-item one for students.

After applying the necessary changes, the final version of the questionnaires underwent a pilot test with eight teachers and students. Analyzing the results through SPSS software revealed the Cronbach's Alpha to be 0.736 and 0.719 for teachers' and students' questionnaires respectively which indicated acceptable levels of internal consistency for our scales.

\section{Attitudes of Teachers towards the Use of L1}

Both rural and urban teachers reported using FL more than L1. The rural teachers reflected that they use L1 more than the urban teachers. In addition, when the education level of the teachers was also factored in, the results indicated that more rural than urban teachers with BA and MA degrees were reported of using L1 (see Table 3).

TABLE 3.

TEACHERS' ESTIMATION OF USING L1 BY LOCATION \& EDUCATION LEVEL

\begin{tabular}{|c|c|c|c|c|c|c|c|c|}
\hline \multicolumn{3}{|c|}{ Location \& Education Level } & \multirow{2}{*}{$\begin{array}{l}\text { Frequency } \\
\text { Total }\end{array}$} & \multicolumn{5}{|c|}{ Percentage of Time for L1 Use by Teacher } \\
\hline & & & & $1 \%-20 \%$ & $21 \%-40 \%$ & $41 \%-60 \%$ & $61 \%-80 \%$ & $81-100 \%$ \\
\hline \multirow[t]{2}{*}{ Location } & Urban & & 40 & $5(12.5 \%)$ & $27(67.5 \%)$ & $8(20 \%)$ & 0 & 0 \\
\hline & Rural & & 20 & $2(10 \%)$ & $6(30 \%)$ & $10(50 \%)$ & $2(10 \%)$ & 0 \\
\hline Location \& & Urban & BA & 34 & $4(11.7 \%)$ & $22(64.7 \%)$ & $8(23.5 \%)$ & 0 & 0 \\
\hline Education & & MA & 6 & $1(16.6 \%)$ & $5(83.3 \%)$ & 0 & 0 & 0 \\
\hline \multirow[t]{2}{*}{ Level } & Rural & BA & 18 & $2(11.1 \%)$ & $4(22.2 \%)$ & $10(55.5 \%)$ & $2(11.1 \%)$ & 0 \\
\hline & & MA & 2 & 0 & $2(100 \%)$ & 0 & 0 & 0 \\
\hline
\end{tabular}

On the whole, according to Table 3, the results showed that the first hypothesis of this study was partially rejected. More rural than urban teachers reported using L1 for teaching difficult grammar rules and vocabulary, checking comprehension, and class management. The overall average point for all items is 4.27 for rural teachers whereas it is 4.00 .

\section{L1 Use and Teaching Grammar}

Items number 1 and 3 in teachers' questionnaire check teachers' attitudes towards use of L1 in teaching grammar; so the frequency total for analyzing this criterion is considered $40 \times 2$ for urban teachers and $20 \times 2$ for rural teachers. With regard to L1 use for grammar teaching rural teachers supported L1 use more than their urban counterparts. As far as the education level of the teachers is concerned more teachers with BA than MA in both rural and urban areas favored L1 use for teaching hard grammatical structures and rules. Table 4 shows the detailed figures and percentages relating to the attitudes of teachers towards L1 use in teaching grammar. 
TABLE 4.

TEACHERS' ESTIMATION OF L1 USE IN GRAMMAR TEACHING By LOCATION \& EDUCATION LEVEL

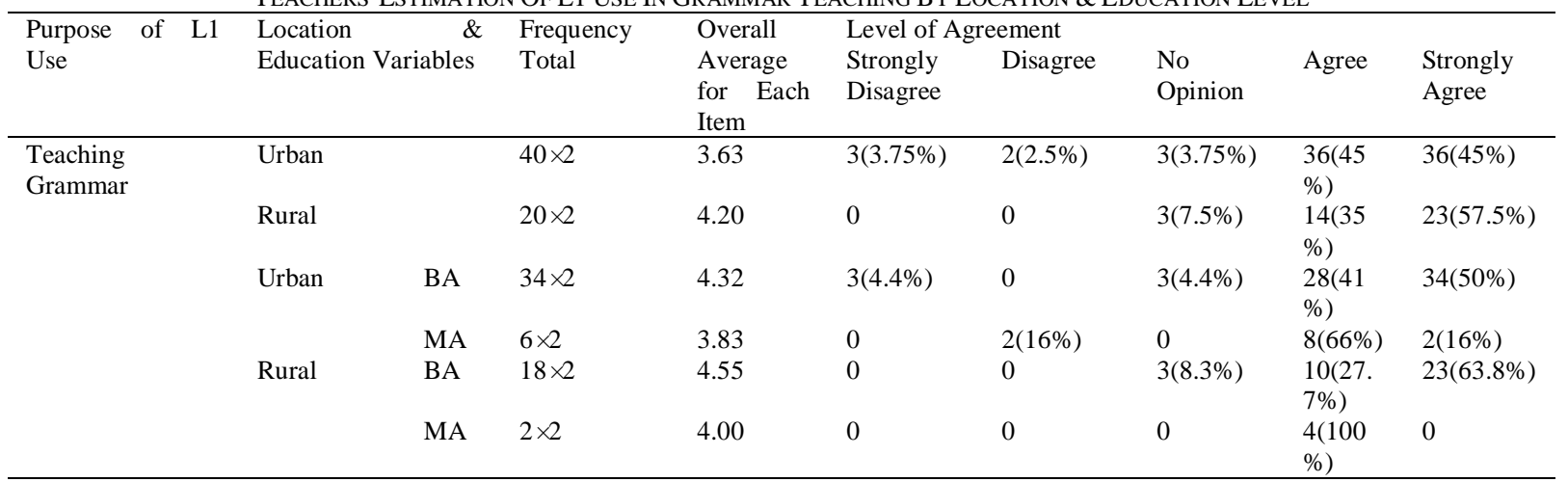

As it is depicted in Table 4, rural teachers $(M=4.20, S D=0.846)$ on the average agreed with $\mathrm{L} 1$ use for teaching grammar more than urban teachers $(\mathrm{M}=3.63, \mathrm{SD}=1.325)$. Independent-samples t test indicated a relationship between L1 use for teaching grammar and the location of variable, $\mathrm{t}(58)=-1.973, \mathrm{p}=0.053$.

\section{L1 Use and Vocabulary Teaching}

Two items, number 2 and 7, in teachers' questionnaire pertaining to L1 use in teaching vocabulary were considered. So again the frequency total for analyzing this factor was multiplied by two. As Table 5 indicates L1 use for teaching vocabulary was more supported by the rural teachers than the urban ones. Contrary to what Table 4 showed teachers with MA degrees were more supportive of L1 use for teaching vocabulary than BA holders in both rural and urban areas. Also, it shows that MA holders either agree or strongly agree with the idea of L1 use for vocabulary teaching in junior high schools whereas at least $30 \%$ of the teachers with BA in urban areas and 20\% of BA holders in rural areas either disagree or strongly disagree with this issue.

TABLE 5.

TEACHERS' ESTIMATION OF L1 USE IN TEACHING VOCABULARY By LOCATION \& EDUCATION LEVEL

\begin{tabular}{|c|c|c|c|c|c|c|c|c|c|}
\hline \multirow{2}{*}{$\begin{array}{l}\text { Purpose of L1 } \\
\text { Use }\end{array}$} & \multirow{2}{*}{$\begin{array}{l}\text { Location } \\
\text { Education }\end{array}$} & \multirow{2}{*}{$\begin{array}{r}\& \\
\text { ables }\end{array}$} & \multirow{2}{*}{$\begin{array}{l}\text { Frequency } \\
\text { Total }\end{array}$} & \multirow{2}{*}{$\begin{array}{l}\text { Overall } \\
\text { Average } \\
\text { for Each } \\
\text { Item }\end{array}$} & \multicolumn{5}{|c|}{ Level of Agreement } \\
\hline & & & & & $\begin{array}{l}\text { Strongly } \\
\text { Disagree }\end{array}$ & Disagree & $\begin{array}{l}\text { No } \\
\text { Opinion }\end{array}$ & Agree & $\begin{array}{l}\text { Strongly } \\
\text { Agree }\end{array}$ \\
\hline \multirow[t]{6}{*}{$\begin{array}{l}\text { Teaching } \\
\text { Vocabulary }\end{array}$} & Urban & & $40 \times 2$ & 4.16 & $5(6.25 \%)$ & $16(20 \%)$ & $\begin{array}{l}15(18.75 \\
\%)\end{array}$ & $\begin{array}{l}24(30 \\
\%)\end{array}$ & $20(25 \%)$ \\
\hline & Rural & & $20 \times 2$ & 4.26 & $2(5 \%)$ & $6(15 \%)$ & $3(7.5 \%)$ & $\begin{array}{l}12(30 \\
\%)\end{array}$ & $17(42.5 \%)$ \\
\hline & Urban & BA & $34 \times 2$ & 3.32 & $5(7.3 \%)$ & $16(23.5 \%)$ & $15(22 \%)$ & $\begin{array}{l}16(23 . \\
5 \%)\end{array}$ & $16(23.5 \%)$ \\
\hline & & MA & $6 \times 2$ & 4.33 & 0 & 0 & 0 & $\begin{array}{l}8(66.6 \\
\%)\end{array}$ & $4(33.3 \%)$ \\
\hline & Rural & BA & $18 \times 2$ & 3.83 & $2(5.55 \%)$ & $6(16.6 \%)$ & $3(8.3 \%)$ & $\begin{array}{l}10(27 . \\
7 \%)\end{array}$ & $15(41.6 \%)$ \\
\hline & & MA & $2 \times 2$ & 4.50 & 0 & 0 & 0 & $2(50 \%)$ & $2(50 \%)$ \\
\hline
\end{tabular}

As revealed in Table 5, independent-samples t test indicated no relationship between L1 use for teaching vocabulary and the location variable, $\mathrm{t}(58)=-0.455, \mathrm{p}=0.651$. Rural teachers $(\mathrm{M}=4.26, \mathrm{SD}=0.691)$ on the average agreed with $\mathrm{L} 1 \mathrm{use}$ for teaching vocabulary more than urban teachers $(\mathrm{M}=4.16, \mathrm{SD}=0.985)$.

\section{L1 Use and Comprehension Check}

Item number 8 deals with using L1 for checking students' comprehension in EFL classrooms. $80 \%$ of rural teachers and $75 \%$ of urban teachers chose agree or strongly agree for the eighth item in completing their questionnaires (see Table 6).

TABLE 6.

TEACHERS' ESTIMATION OF L1 USE AND COMPREHENSION CHECK By LOCATION \& EDUCATION LEVEL

\begin{tabular}{|c|c|c|c|c|c|c|c|c|c|}
\hline \multirow{2}{*}{$\begin{array}{l}\text { Purpose of } \\
\text { L1 Use }\end{array}$} & \multirow{2}{*}{\multicolumn{2}{|c|}{$\begin{array}{l}\text { Location } \& \\
\text { Education Variables }\end{array}$}} & \multirow{2}{*}{$\begin{array}{l}\text { Frequency } \\
\text { Total }\end{array}$} & \multirow{2}{*}{$\begin{array}{l}\text { Overall } \\
\text { Average for } \\
\text { Each Item }\end{array}$} & \multicolumn{5}{|c|}{ Level of Agreement } \\
\hline & & & & & $\begin{array}{l}\text { Strongly } \\
\text { Disagree }\end{array}$ & Disagree & No Opinion & Agree & $\begin{array}{l}\text { Strongly } \\
\text { Agree }\end{array}$ \\
\hline \multirow{6}{*}{$\begin{array}{l}\text { Comprehen } \\
\text { sion Check }\end{array}$} & Urban & & 40 & 4.16 & 0 & $3(7.5 \% 0$ & $7(17.5 \%)$ & $20(50 \%)$ & $10(25 \%)$ \\
\hline & Rural & & 20 & 3.93 & 0 & 0 & $4(20 \%)$ & $8(40 \%)$ & $8(40 \%)$ \\
\hline & Urban & BA & 34 & 4.05 & 0 & $3(8.8 \%)$ & $6(17.6 \%)$ & $16(47 \%)$ & $9(26.4 \%)$ \\
\hline & & MA & 6 & 4.00 & 0 & 0 & $1(16.6 \%)$ & $4(66.6 \%)$ & $1(16.6 \%)$ \\
\hline & Rural & $\mathrm{BA}$ & 18 & 4.27 & 0 & 0 & $3(16.6 \%)$ & $7(38.8 \%)$ & $8(44.4 \%)$ \\
\hline & & MA & 2 & 3.50 & 0 & 0 & $1(50 \%)$ & $1(50 \%)$ & 0 \\
\hline
\end{tabular}


As it is given in Table 6, rural teachers $(\mathrm{M}=3.93, \mathrm{SD}=0.827)$ on the average agreed with $\mathrm{L} 1$ use for checking students' comprehension less than urban teachers $(M=4.16, S D=0.791)$. Independent-samples t test shows no significant relationship between L1 use for comprehension check and the variable of place, $\mathrm{t}(58)=1.116, \mathrm{p}=0.269$.

L1 Use and Class Management

For using L1 in class management which was item number 10 all urban teachers and $95 \%$ of rural teachers agreed or strongly agreed with the idea (see Table 7).

TABLE 7.

TEACHERS' ESTIMATION OF L1 USE AND ClASS MANAGEMENT By LOCATION \& EDUCATION LEVEL

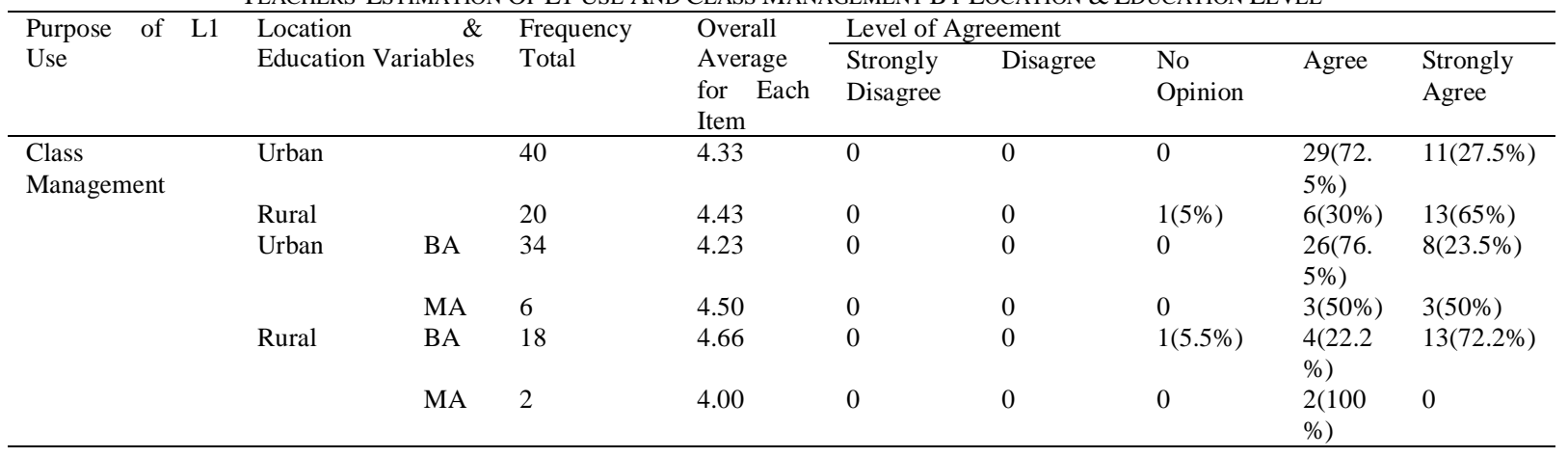

Based on what has given in Table 7, independent-samples t test showed no significant relationship between L1 use for class management and the variable of place, $\mathrm{t}(58)=-0.737, \mathrm{p}=0.464$. Rural teachers $(\mathrm{M}=4.43, \mathrm{SD}=0.568)$ on the average agreed with $\mathrm{L} 1 \mathrm{use}$ for controlling the class more than urban teachers $(\mathrm{M}=4.33, \mathrm{SD}=0.479)$.

Attitudes of Students towards the Use of L1

Most students report that their teachers use the L1 21-60\% in FL classrooms. Fifty percent of rural students reported that their teachers use the L1 41-60\%, whereas fifty-three percent of urban students indicate that their teachers use the L1 21-40\%.

TABLE 8.

LEARNERS' ESTIMATION OF TEACHER AMOUNT OF L1 USE BY LOCATION

\begin{tabular}{|c|c|c|c|c|c|c|c|}
\hline & & \multirow{2}{*}{$\begin{array}{l}\text { Frequency } \\
\text { Total }\end{array}$} & \multicolumn{5}{|c|}{ Percentage of Time for L1 Use by Teacher } \\
\hline & & & $1-20 \%$ & $21-40 \%$ & $41-60 \%$ & $61-80 \%$ & $81-100 \%$ \\
\hline \multirow[t]{2}{*}{ Location } & Urban & 30 & $7(23.3 \%)$ & $16(53.3 \%)$ & $7(23.3 \%)$ & 0 & 0 \\
\hline & Rural & 30 & $2(6.66 \%)$ & $8(26.6 \%)$ & $15(50 \%)$ & $5(16.6 \%)$ & 0 \\
\hline
\end{tabular}

Based on what is considerable in Table 8, more than sixteen percent of rural students believe that their English teachers speak Persian in 61-80\% of the class time. However, none of the urban students support this belief. As was mentioned in the analysis of teachers' attitudes towards the use of L1, the second hypothesis is also rejected by the students in this study.

\section{Students' Estimation of L1 Use and FL Learning}

More rural than urban students reported that their English teachers use L1 for teaching; however it includes difficult grammar rules and vocabulary, checking comprehension, class management. The overall average point for all items is 4.18 for rural students whereas it is 3.81 for urban students. Table 11 shows the students' estimation of L1 use regarding all the item groups.

TABLE 9.

STUDENTS' Estimation OF L1 USE AND FL LEARNING By LOCATION

\begin{tabular}{|c|c|c|c|c|c|c|c|c|}
\hline \multirow{2}{*}{$\begin{array}{l}\text { L1 Use and } \\
\text { FL } \\
\text { Development }\end{array}$} & \multirow[t]{2}{*}{ Location } & \multirow{2}{*}{$\begin{array}{l}\text { Frequency } \\
\text { Total }\end{array}$} & \multirow{2}{*}{$\begin{array}{l}\text { Overall } \\
\text { Average } \\
\text { for } \\
\text { Each } \\
\text { Item }\end{array}$} & \multicolumn{5}{|c|}{ Level of Agreement } \\
\hline & & & & $\begin{array}{l}\text { Strongly } \\
\text { Disagree }\end{array}$ & Disagree & $\begin{array}{l}\text { No } \\
\text { Opinion }\end{array}$ & Agree & $\begin{array}{l}\text { Strongly } \\
\text { Agree }\end{array}$ \\
\hline Teaching & Urban & $30 \times 2$ & 3.86 & $1(1.6 \%)$ & $3(5 \%)$ & $4(6.6 \%)$ & $35(58.3 \%)$ & $17(28.3 \%)$ \\
\hline Grammar & Rural & $30 \times 2$ & 4.26 & 0 & 0 & $5(8.3 \%)$ & $38(63.3 \%)$ & $17(28.3 \%)$ \\
\hline Teaching & Urban & $30 \times 2$ & 3.66 & $4(6.6 \%)$ & $17(28.3 \%)$ & $8(13.3 \%)$ & $24(40 \%)$ & $7(11.6 \%)$ \\
\hline Vocabulary & Rural & $30 \times 2$ & 4.06 & 0 & $3(5 \%)$ & $8(13.3 \%)$ & $38(63.3 \%)$ & $11(18.3 \%)$ \\
\hline Comprehension & Urban & 30 & 3.96 & 0 & $5(16.6 \%)$ & $2(6.6 \%)$ & $12(40 \%)$ & $11(36.6 \%)$ \\
\hline Check & Rural & 30 & 4.43 & 0 & 0 & $3(10 \%)$ & $17(56.6 \%)$ & $10(33.3 \%)$ \\
\hline Class & Urban & 30 & 4.36 & 0 & 0 & $4(13.3 \%)$ & $11(36.6 \%)$ & $15(50 \%)$ \\
\hline Management & Rural & 30 & 4.43 & 0 & 0 & 0 & $17(56.6 \%)$ & $13(43.3 \%)$ \\
\hline
\end{tabular}

According to Table 11. the independent-samples t test indicated a relationship between L1 use for teaching grammar and the location variable, $\mathrm{t}(58)=-1.752, \mathrm{p}=0.085$. Rural students $(\mathrm{M}=4.26, \mathrm{SD}=0.639)$ on the average agreed with $\mathrm{L} 1$ use for teaching grammar more than urban students $(\mathrm{M}=3.86, \mathrm{SD}=1.074)$. Also, regarding to the use of $\mathrm{L} 1$ in 
controlling the class the independent-samples $t$ test revealed no significant relationship between L1 use for class management and the variable of place, $\mathrm{t}(58)=-0.416, \mathrm{p}=0.679$. Rural students $(\mathrm{M}=4.43, \mathrm{SD}=0.504)$ on the average agreed with $\mathrm{L} 1 \mathrm{use}$ for controlling the class more than urban students $(\mathrm{M}=4.36, \mathrm{SD}=0.718)$.

The Effect of Using Translation on Students' Attitudes towards L1 Use

For the last part of the study fifteen students out of thirty-one participants in each control or experimental group of the first part of this research were randomly given the same students' questionnaire. The results revealed that the students in the experimental group who had experienced the translation of the intended grammatical structures reported the use of L1 by their teacher more than the students in the control group.

TABLE 10.

LEARNERS' ESTIMATION OF TEACHER AMOUNT OF L1 USE BY GROUP

\begin{tabular}{|c|c|c|c|c|c|c|c|}
\hline & \multirow{2}{*}{$\begin{array}{l}\text { Control } \\
\text { Experimental }\end{array}$} & \multirow{2}{*}{$\begin{array}{l}\text { Frequency } \\
\text { Total } \\
15 \\
15\end{array}$} & \multicolumn{5}{|c|}{ Percentage of Time for L1 Use by Teacher } \\
\hline Group & & & $5(33.3 \%)$ & $5(33.3 \%)$ & $5(33.3 \%)$ & 0 & 0 \\
\hline
\end{tabular}

As Table 10 shows $80 \%$ of the students in the experimental group and about $67 \%$ of the students in the control group believed that their English teachers use Persian 21-60\% of the class time. Also, more than $13 \%$ of the students in the experimental group and none of the students in the control group indicated that their English teachers use Persian 61 $80 \%$ of the class time. Another significant difference was reported in the amount of 1-20\% of the time which the L1 is used by EFL teachers which turned out to be more than $33 \%$ for the control group and less than $7 \%$ for the experimental group.

TABLE 11 .

STUDENTS' ESTIMATION OF L1 USE AND FL LEARNING By GROUP

\begin{tabular}{|c|c|c|c|c|c|c|c|c|}
\hline \multirow{2}{*}{$\begin{array}{l}\text { L1 Use and } \\
\text { FL } \\
\text { Development }\end{array}$} & \multirow[t]{2}{*}{ Group } & \multirow{2}{*}{$\begin{array}{l}\text { Frequency } \\
\text { Total }\end{array}$} & \multirow{2}{*}{$\begin{array}{l}\text { Overall } \\
\text { Average } \\
\text { for } \\
\text { Each } \\
\text { Item }\end{array}$} & \multicolumn{5}{|c|}{ Level of Agreement } \\
\hline & & & & $\begin{array}{l}\text { Strongly } \\
\text { Disagree }\end{array}$ & Disagree & $\begin{array}{l}\text { No } \\
\text { Opinion }\end{array}$ & Agree & $\begin{array}{l}\text { Strongly } \\
\text { Agree }\end{array}$ \\
\hline Teaching & Control & $15 \times 2$ & 3.86 & 0 & $4(13.3 \%)$ & $2(6.66 \%)$ & $18(60 \%)$ & $6(20 \%)$ \\
\hline Grammar & $\begin{array}{l}\text { Experim } \\
\text { ental }\end{array}$ & $15 \times 2$ & 4.26 & 0 & 0 & $2(6.66 \%)$ & $18(60 \%)$ & $10(3.33 \%)$ \\
\hline Teaching & Control & $15 \times 2$ & 3.73 & $2(6.66 \%)$ & $2(6.66 \%)$ & $4(13.3 \%)$ & $16(53.3 \%)$ & $6(20 \%)$ \\
\hline Vocabulary & $\begin{array}{l}\text { Experim } \\
\text { ental }\end{array}$ & $15 \times 2$ & 4.20 & 0 & 0 & $4(13.3 \%)$ & $16(53.3 \%)$ & $10(3.33 \%)$ \\
\hline Comprehension & Control & 15 & 4.66 & 0 & $2(13.3 \%)$ & $1(6.66 \%)$ & $6(40 \%)$ & $6(40 \%)$ \\
\hline Check & $\begin{array}{l}\text { Experim } \\
\text { ental }\end{array}$ & 15 & 4.33 & 0 & 0 & 0 & $10(66.6 \%)$ & $5(33.3 \%)$ \\
\hline Class & Control & 15 & 4.04 & 0 & 0 & $2(13.3 \%)$ & $5(33.3 \%)$ & $8(53.3 \%)$ \\
\hline Management & $\begin{array}{l}\text { Experim } \\
\text { ental }\end{array}$ & 15 & 4.26 & 0 & 0 & 0 & $11(73.3 \% 0$ & $4(26.6 \%)$ \\
\hline
\end{tabular}

As it is considerable in Table 11, students in the experimental group are more supportive of L1 use in the classroom. In all parts of the questionnaire except one part students in the experimental group showed the higher interest in L1 use. However, in some parts the difference is not great.

\section{DISCUSSION, CONCLUSION AND IMPLICATION}

The first hypothesis anticipated that EFL teachers and students in rural areas use L1 no more than teachers and students in urban EFL classrooms. On the whole, the results show that the first hypothesis of this study is somehow rejected. More rural than urban teachers and students report using L1, however it had difficult grammar rules and vocabulary, and class management. The overall average point for all items is 4.27 for rural teachers whereas it is 4.00 for urban teachers.

Analyzing the item groups reveals that in all groups except the comprehension group more rural than urban teachers support the use of L1 in FL classrooms. That is rural teachers on the average agree with L1 use for checking students' comprehension less than urban teachers. One explanation for this might be that urban classrooms are more crowded than rural ones and checking the students' comprehension in English might take more time. Furthermore, urban classes are less homogeneous and variety in the students' proficiency level makes comprehension check more problematic if it is done in English.

The findings of the first part of the study are in agreement with previous research results of Schweers (1999), Duff and Polio (1990), Dujmovic (2007), Rolin-Ianziti and Varshney (2008), Prodromou (2002), Burden (2000), and Samadi (2011). Findings of the mentioned research have shown that the role of L1 is vitally important in a way that is taken into consideration by FL/L2 teachers and tend to be used in various degrees and for different purposes which are supported by the present study. Schweers (1999) showed that over eighty percent of students found the use of L1 in the classroom 
useful. The present study reveals the same results as around $80 \%$ of the students in rural and urban areas are supportive or strongly supportive of L1 use in EFL classrooms for different purposes.

According to the results of a research carried out by Prodromou (2002) about the usage of L1 in ESL classrooms on Greek students on three beginner, intermediate, and advanced students, the idea of using both mother tongue and native was supported by $60 \%$ of the respondents, while the advanced ones supported the idea of using L1 more. Results of the present study reveals similar results as students with higher English grades are less supportive of L1 use.

However, the results contradict the findings of Storch and Wigglesworth (2003) who report that intermediate level students in university were reluctant to use their shared MT because it would slow down their progress in EFL learning by adding another unnecessary step (translation from L1 to L2) and, furthermore, they intrinsically believed they should use as much TL as possible in class. The findings of the present study reveal that elementary level students support L1 use in foreign language learning for different purposes and they are mostly reluctant of an English-only method. They also indicate that translation is not only an unnecessary step but it can sometimes be considered as an auxiliary step in students' comprehension.

Moreover, the results of comparing the attitudes of teachers by their level of education lead to somewhat different findings. Samadi's (2011) research showed that teachers with MA degree report using L1 more than teachers with BA degrees. The present study indicates that teachers with MA degrees are less supportive of L1 use than teachers with BA degrees. All rural and urban teachers with MA degrees believe that they use L1 in EFL classrooms less than $40 \%$ of the class time. An explanation for this new finding might be that Samadi conducted his research at the university level in which teachers are mostly teaching the subject not the language. In addition, different studies show that university teachers use code-switching as a teaching strategy not because of their lack of knowledge. In junior high schools' context, the conditions are completely different because the students are at elementary levels and they need more exposure to the foreign language. Teachers with MA degrees are probably more aware of teaching principles and methods and more experienced in providing a viable learning environment than their BA holder colleagues.

The findings of this research also contradict the results of Mahmoudi and Yazdi's (2011) study which revealed that high-achieving and low-achieving students supported the idea that L2 should be highly prioritized in L2 classes. They conducted their research through observation and interview which are different from the methods of this research. The students in the present study indicate that L1 would be a great asset if used properly for easing comprehension of difficult subjects.

The second hypothesis predicted that there is not a significant relationship between the use of translation and the students' attitudes towards the use of L1. The results reveal that the students in the experimental group who experienced translation of the intended grammatical structures reported the use of L1 by their teacher more than the students in the control group. It also indicates that there is a significant relationship between the way of teaching and the students' attitudes towards the L1 use in EFL classroom. In other words, the third null hypothesis is rejected.

The findings of this part of the study indicate that the students' attitudes towards the use of L1 in EFL classrooms are flexible and can be easily changed through using different teaching techniques and methods. EFL teachers' attitudes towards the use of L1 directly affect students' attitudes and teachers have the most responsibility in directing the students' ideas to the most advantageous ways of EFL learning.

The results of both studies in terms of positive attitude and feedback of the students, based on the observations, is in line with the results of the research conducted by Brice and Roseberry-McKibbin (2001), Ferguson (2003), Clegg and Afitska (2011), and Moduopela (2013).

Results of a recent study conducted by Adriosh and Razi (2019) in terms of having a positive attitude toward translation and code-switching in bilingual classroom for EFL students was in line with the results of the present study. On the contrary of the nature of both conducted research in which both teachers and students used code-switching strategies at the class for clarification function, some researchers like Bahous et al. (2014) encountered those EFL professors who were not aware of the positive sides of exploiting first language to learn the second language better.

Furthermore, as the results show, there is a significant difference between the attitudes of rural and urban students and teachers towards L1 use and EFL learning in most sections of the study. These findings might refer to the fact that learning and teaching location can greatly affect the process of learning and teaching. Rural students are less likely to have access to necessary learning equipment in and out of school. If rural teachers have these differences in their mind, they can get the best out of the existing learning and teaching facilities. Finally, it might be concluded from the last part of the study that teaching methods and techniques not only affect the learning process but also they can modify the learners' attitudes towards the EFL learning. Foreign language teachers will be able to improve the learners' attitudes towards FL learning if they insert suitable and viable techniques into the learning environment.

It can be suggested that teachers be familiarized with advantages of using learners' mother tongue in EFL classrooms and they should be reasonably given enough flexibility to use this resource constructively. In particular, language teachers can use translation from English to Persian or vice versa, as a communicative task to promote their learners' linguistic accuracy. 


\section{REFERENCES}

[1] Adriosh, M., \& Raz1, Ö. (2019). Teacher's Code Switching in EFL Undergraduate Classrooms in Libya: Functions and Perceptions. SAGE Open. https://doi.org/10.1177/2158244019846214. Doi.org/10.1177/2158244019846214.

[2] Bahous, R. N., Nabhani, M. B., \& Bacha, N. N. (2014). Code switching in higher education in a multilingual environment: A Lebanese exploratory study. Language Awareness, 23, 353-368.

[3] Brice, A. \& Roseberry-McKibbin, C. (2008). Choice of languages in instruction. Teaching Exceptional Children, 33(4): 10-16.

[4] Brown, H. D. (2000). Principles of language learning and teaching ( $4^{\text {th }}$ ed.). White Plains, NY: Addison Wesley, Longman.

[5] Burden, P. (2000). The use of the students' mother tongue in monolingual English "Conversation" classes at Japanese universities. The Language Teacher Online, 24(6), 5-10. Retrieved on January 12, 2011 from http://www.jaltpublications.org/tlt/articles/2000/06/burden.

[6] Clegg, J. \&Afitska, O. (2011). Teaching and learning in two languages in African classrooms. Comparative Education, 47(1): 61-77.

[7] Deller, S. \& Rinvolucri, M. (2002). Using the Mother Tongue. London: Delta Publishing.

[8] Dujmovic, M. (2007). The use of Croatian in the EFL classroom. Metodickiobzori, 2 (1), 91-100. Retrieved on January 12, 2011 from http://hrcak.srce.hr/file/19437.

[9] Ellis, R. (2008). The study of second language acquisition. Oxford: Oxford University Press.

[10] Ferguson, G. (2003). Classroom code-switching in post-colonial contexts: Functions, attitudes and policies. AILA Review, 16: 38-51.

[11] Gabrielatos, C. (2001). L1 use in ELT: Not a skeleton, but a bone of contention. Bridges, 6. Retrieved on January 12, 2011 from http://www.thrace-net.gr/bridges/6/.

[12] Jahan Shuchi, I \& Shafiqul Islam, A. B. M. (2016). Teachers' and students' attitudes towards L1 use in EFL classrooms in the contexts of Bangladesh and Saudi Arabia. English Language Teaching, 9(12): 62-73.

[13] Karathanos, K.A. (2005). Exploring the self-reported perspectives and behaviors of predominantly English-speaking teachers regarding the incorporation of English language learners' native languages into instruction. Unpublished doctoral dissertation, Kansas State University, Manhattan, Kansas.

[14] Mahmoudi, L \& Yazdi, Y. (2011). The use of Persian in the EFL classroom. English Language Teaching, 4 (1), 135-140.

[15] Moduopela, O.R. (2013). Code-switching as a teaching strategy: Implications for English Language teaching and learning in a multilingual society. IOSR Journal of Humanities and Social Sciences, 14(2): 92-94.

[16] Naiman, Neil (1974). The use of elicited imitation in second language acquisition research. Working Papers on Bilingualism, 2 , 1-37.

[17] Nation, I.S.P. (1978). Translation and the teaching of meaning: Some techniques. ELT Journal, 32 (3), 171-175.

[18] Nation, P. (2003). The role of the first language in foreign language learning. The Asian EFL journal, 5 (2). Retrieved on December 10, 2011 from http://www.asian-efl-journal. com/june_2003_PN.html.

[19] Polio, C. G. \& Duff, P. A. (1994). Teachers' language use in university foreign language classrooms: A qualitative analysis of English and target language alternation. The Modern Language Journal, 78, 313-326.

[20] Prodromou, L. (2002). The role of the mother tongue in the classroom. Language Teaching Issues, 166.

[21] Raeisi, M. \& Raeisi, M. (2019). Identifying code-switching cases and exploring their inter-sentential and intra-sentential patterns in Persian-English bilingual Classrooms. Journal of Applied Linguistics and Language Research (JALLR), 6(4): 67-79.

[22] Rolin-Ianziti, J. \& Brownlie, S. (2002). Teacher use of learners' native language in the foreign language classroom. The Canadian Modern Language Review, 58(3), 402-426.

[23] Rolin-Ianziti, J. \& Varshney, R. (2008). Students' views regarding the use of first language: An exploratory study in a tertiary context maximizing target language use. The Canadian Modern Language Review, 65, 249-273.

[24] Schweers, C. W. (1999). Using L1 in the L2 classroom. Retrieved on March 14, 2011, from http://exchanges.state.gov/forum/vols/vol37/no2/p6.htm.

[25] Skutnabb-Kangas, T. (1981). Bilingualism or not: The education of minorities. Clevedon: Multilingual Matters.

[26] Stern, H. H. (1983). Fundamental concepts of language teaching. Oxford: Oxford University Press.

[27] Titford, C. (1983). Translation for advanced learners. ELT journal, 37(1): 52-57.

[28] Vaezi, S. \& Mirzaei, M. (2007). The effect of using translation from L1 to L2 as a teaching technique. Retrieved on July 22, 2011, from www. hltmag.co.uk/sep07/mart03.rtf.

[29] Van Els, T., Bongaerts, T., Extra, G., Van Os, C. \& Janssen-van, A. D. (1984). Applied linguistics and the learning and teaching of foreign languages, London: Edward Arnold.

[30] Wales, J. \& Sanger, L. (2001). Wikipedia. Org. Retrieved on July 11, 2012, from http:/ / en.wikipedia.org/wiki/Wikipedia.

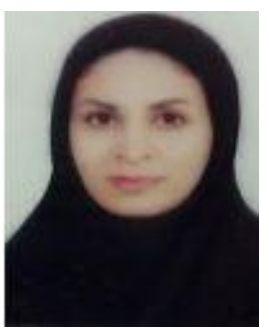

Mina Raeisi, Lecturer, Department of English, Isfahan (Khorasgan) Branch, Islamic Azad University, Isfahan, Iran

Mina holds Master's degree in English translation from Islamic Azad University of Isfahan (Khorasgan) Branch. She is now the lecturer of IAUKB and has been taught a variety of courses including English translation, specialized English of different majors there, from 2013 to 2020 and commenced teaching IELTS on 2018. She has cooperated with IAUKH English Department to hold RTETL Conference on 2013 and work as the executive director of RELP Journal, from 2013 to 2017. She has published many articles in the areas of bilingualism, self-directed learning, teaching translation, code-switching patterns and text analysis and authored or translated five books. Her latest book published in 2018, Handbook of Energy Audits. Ms. Raeisi is interested in diachronic corpora and using different types of technology to improve teaching quality. NEST and NNEST and social justice are among her field of interest. 


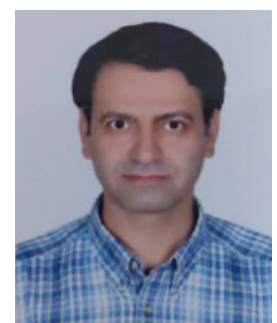

Hossein Ghaiyoomian, Sheikhbahaee University, Isfahan, Iran

Hossein is a master holder in English teaching as a foreign language from Sheikhbahaee University. He has been working as an English teacher in language institutes and high schools of Isfahan for more than 25 years. $\mathrm{He}$ is also cooperating with a couple of translation institutes and websites as a translator. His fields of interest include translation and critical discourse analysis (CDA). His latest article titled "The effect of using translation on learning grammatical structures: A case study on Iranian Junior high school students" has been published in Research in English Language Pedagogy (RELP) Journal.

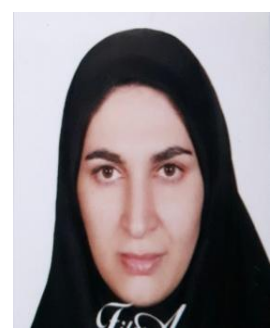

Massome Raeisi, Department of English, Isfahan (Shareza) Branch, Islamic Azad University, Isfahan, Iran Massome has just finished her master from IAUSH majoring Translation Studies. She is now working on two articles in the field of translation studies and teaching. She translated a book entitled: An Introduction to Polymer compounding (two volumes) which is going to publish in Islamic Azad University of Shahreza Publication. Ms. Raeisi's field of interest is virtual reality (VR) and the usage of technology in teaching. 